\title{
Dashboard Monitoring System Berbasis Web Sebagai Pemantau Layanan liteBIG Instant Messenger
}

\author{
Gigih Forda Nama1,* ${ }^{1}$, Abdul Munif Hanafi², Muhammad Bagus Nurfaif2, M Tesar Sandikapura³ \\ 1Teknik Informatika Universitas Lampung, Indonesia \\ 2Teknik Elektro Universitas Lampung, Indonesia \\ ${ }^{3}$ CEO LiteBig, Indonesia \\ (corresponding author) gigih@eng.unila.ac.id*, am.hanafi@students.unila.ac.id, m.bagus66@gmail.com, tesar@gmail.com
}

\begin{abstract}
Nowaday almost all of smart phone already installed an instant messaging service as a communication tool due to the instant messaging service was more cost effective than short message service (SMS). The messaging system should provided a good services to all users and ensure the message can be sent quickly and accurately. This service reliability should also be maintained to ensure the quality of service and to avoid user inconvenience. So, there needs a software system for monitoring the status of the service and can be accessed any time and anywhere. PT.Sandika Cahaya Mandiri has an instant-messaging services products with the brand name liteBIG Messenger. These companies need a software for monitoring liteBIG Messenger service. With the monitoring software services, administrator can monitoring in realtime the status of major services on each server, the use of resources (CPU, memory, and hard drive), and new user statistics of liteBIG Messenger through a web interface. Administrator will also receive notifications when there are any problems with the service, so that the problem can be early identified and downtime can be reduced.
\end{abstract}

Key words- monitoring, service monitoring, instant messaging, ssh monitoring, LiteBig

Intisari- Saat ini hampir semua pengguna ponsel pintar menggunakan layanan perpesanan instan sebagai media komunikasi, dikarenakan layanan perpesanan instan lebih hemat biaya dengan hanya menggunakan jaringan internet dibandingkan layanan pesan singkat (SMS). Layanan yang diberikan harus dapat melayani pengguna dengan baik agar pesan yang dikirim oleh pengirim dapat diterima oleh penerima dengan cepat dan akurat. Layanan ini juga harus dijaga keandalannya untuk menjamin kualitas pelayanan dan untuk menghindari ketidaknyamanan pengguna. Sehingga, diperlukan adanya sistem pemantauan berupa perangkat lunak untuk pengawasan status layanan setiap saat dapat diakses dari manapun dan kapanpun. PT.Sandika Cahaya Mandiri memiliki produk layanan perpesanan instan dengan brand name liteBIG Messenger. Perusahaan ini memerlukan perangkat lunak untuk pemantauan layanan liteBIG Messenger. Dengan adanya perangkat lunak pemantauan layanan, petugas pemantauan dapat melihat secara realtime status layanan utama pada setiap komputer server, pemakaian sumber daya (CPU, Memory, dan Harddisk), dan statistik pengguna baru liteBIG Messenger melalui antarmuka web. Petugas pemantauan juga akan mendapat pemberitahuan ketika terjadi masalah pada layanan sehingga masalah dapat lebih dini diketahui dan downtime dapat dikurangi.

Kata Kunci- monitoring, senvice monitoring, instant messaging, ssh monitoring, LiteBig

\section{PENDAHULUAN}

Aplikasi perpesanan instan adalah aplikasi yang wajib ada pada setiap ponsel pintar saat ini. Jenis aplikasi ini menjadi jalur komunikasi utama oleh sebagian besar pengguna ponsel pintar dikarenakan lebih hemat biaya dengan hanya menggunakan jaringan internet dibandingkan layanan pesan singkat (SMS). Aplikasi perpesanan instan harus dapat melayani pengguna dengan baik supaya pesan yang dikirim oleh pengirim dapat diterima oleh penerima dengan cepat dan akurat. Di dalam sebuah sistem layanan perpesanan instan, terdapat beberapa komputer server untuk melayani berbagai macam permintaan dari client. Komputer-komputer server tersebut harus dijaga keandalannya untuk menjaga kualitas pelayanan kepada pengguna. Jika terjadi masalah pada komputer server, maka layanan akan terhenti dan menyebabkan ketidaknyamanan kepada pengguna. Petugas pemantauan tidak dapat secara terus menerus memantau status layanan dikarenakan keterbatasan manusia. Oleh karena itu diperlukan perangkat lunak yang dapat membantu petugas pemantauan untuk memantau layanan secara realtime dan dapat menyampaikan pemberitahuan kepada petugas pemantauan ketika terjadi masalah pada layanan. Pada beberapa penelitian sebelumnya [1][2] telah dikembangkan aplikasi sistem monitoring performa server dan kondisi kelistrikan untuk memastikan bahwa layanan bekerja dengan baik. Dalam penelitian ini selanjutnya dikembangkan perangkat lunak yang berfungsi melakukan 
pemantauan kinerja dari beberapa server LiteBig messenger, aplikasi ini membantu petugas pemantauan agar dapat mengetahui lebih dini masalah yang terjadi pada server utama, sehingga downtime layanan dapat dikurangi.

\section{TINJAUAN PUSTAKA}

A. Server

Di dalam dunia komputasi, server adalah sebuah program komputer atau perangkat yang menyediakan fungsi untuk program atau perangkat lain, yang disebut "client". Arsitektur ini disebut model client-server, dan hasil komputasi didistribusikan di beberapa proses atau perangkat. Server dapat memiliki berbagai fungsi yang sering disebut sebagai "service" atau layanan, seperti berbagi data atau sumber daya di antara beberapa client, atau melakukan komputasi untuk client. Service adalah program-program yang umumnya berjalan latar belakang dan melayani tugas-tugas tertentu yang diperlukan oleh program lain. Sebuah server tunggal dapat melayani beberapa client, dan client tunggal dapat menggunakan beberapa server. Server yang biasanya digunakan adalah database servers, file servers, mail servers, print servers, web servers, game servers, dan application servers [3].

\section{B. Server Aplikasi Mobile}

Sebuah server aplikasi mobile adalah mobile middleware yang membuat sistem back-end dapat diakses aplikasi mobile untuk mendukung pengembangan aplikasi mobile. Sama seperti web server yang menyimpan, memproses, dan memberikan halaman web untuk klien, server aplikasi mobile menjembatani kesenjangan dari infrastruktur yang ada untuk perangkat mobile. Meskipun sebagian besar standar infrastruktur dirancang untuk terhubung ke berbagai jenis vendor, produk, atau teknologi, tetapi sebagian besar perusahaan mengalami kesulitan menghubungkan sistem backend untuk aplikasi mobile, karena perangkat mobile memiliki beberapa tantangan teknologi seperti berikut:

- Sumber daya yang terbatas - perangkat mobile memiliki sumber listrik dan bandwidth yang terbatas

- Konektivitas intermiten - cakupan layanan seluler dan WiFi sering tidak terus menerus

- Sulit untuk mengamankannya - mobilitas dan BYOD (Bring Your Own Device) membuat sulit untuk mengamankan perangkat mobile [4].

\section{Secure Shell (SSH)}

Secure Shell adalah program yang melakukan logging terhadap komputer lain dalam jaringan, mengeksekusi perintah lewat mesin secara remote, dan memindahkan file dari satu mesin ke mesin lainnya. SSH menggunakan kriptografi public key untuk mengenkripsi komunikasi-komunikasi antara dua host. Ada banyak program-program SSH seperti sshd, slogin, scp, dan lain-lain [5].

\section{Aplikasi Web}

Aplikasi web adalah aplikasi perangkat lunak client-server yang dapat dijalankan oleh pengguna melalui web browser. Aplikasi web sangat populer dikarenakan pengguna hanya membutuhkan web browser untuk mengaksesnya tanpa harus memasang perangkat lunak tambahan dan mendukung kompatibilitas cross-platform. Aplikasi web yang umum dipakai adalah webmail, jual beli online, lelang online, layanan perpesanan instan, dan lain-lainnya.

\section{E. Bahasa Pemrograman Python}

Python merupakan salah satu bahasa pemrograman tingkat tinggi dengan tipe bahasa interpreted karena programprogram Python langsung dieksekusi oleh interpreter tanpa harus melalui tahap kompilasi [6]. Python dapat dijalankan dengan dua cara, yakni:

1. Mode command-line

2. Mode script

Python memiliki banyak library yang dapat digunakan oleh programmer pada setiap saat. Ini dapat membuat programmer tidak harus menulis setiap program dari awal, programmer dapat menggunakan hal-hal yang sudah ada di library untuk melakukan banyak hal yang dimungkinkan. Inilah yang membuat Python menjadi salah satu bahasa pemrograman yang begitu kuat [7].

\section{F. Codelgniter Web Framework}

Codelgniter adalah framework yang bersifat open source untuk membuat aplikasi web atau digunakan untuk membangun website dinamis dengan bahasa perograman PHP. Tujuannya adalah untuk mempercepat pengerjaan proyek-proyek daripada harus menulis kode dari awal. Di dalam Codelgniter sudah terdapat satu set pustaka untuk tugas-tugas yang biasa diperlukan, serta antarmuka yang sederhana dan struktur logis untuk mengakses pustaka tersebut [6]. Codelgniter menggunakan model pengembangan populer yaitu Model-View-Controller. View dan Controller adalah bagian penting dari framework Codelgniter, dan Model adalah opsional. Codelgniter memiliki performa yang lebih cepat dibandingkan dengan framework PHP yang lainnya [8]. 


\section{G. Penelitian Yang Berhubungan}

Riyanto membuat aplikasi sistem monitoring suhu server berbasis web [9], pada penelitian ini menjelaskan bahwa suhu ruang server sangat perlu untuk di pantau dikarenakan apabila suhu ruang server melebihi batas toleransi, pengelola dapat mengetahui dan menindak lanjuti untuk meminimalisir terjadinya kerusakan pada server. Gigih Forda Nama dalam penelitiannya [8], menjelaskan bahwa server gateway internet perlu dimonitoring secara berkala untuk memastikan bahwa layanan internet berjalan dengan baik, dalam penelitian lainnya [10][11][12] Gigih dkk menggunakan bahasa pemrograman Python sebagai engine utama aplikasi yang digunakan untuk pemrosesan data, Python terbukti berjalan dengan baik dan stabil dalam pengembangan aplikasi web maupun mobile.

\section{KEBUTUHAN SISTEM}

Perangkat lunak yang akan digunakan untuk pemantauan status layanan pada perusahaan ini memiliki kebutuhan sebagai berikut:

Kebutuhan fungsional:

1. Dapat mengetahui nilai persentase pemakaian sumber daya CPU, memory, dan harddisk.

2. Dapat mengetahui status sebuah layanan.

3. Dapat mengetahui statistik pengguna baru hari ini, kemarin, minggu ini, bulan ini, dan total pengguna.

4. Dapat mengetahui status layanan perpesanan dan mendapatkan nilai delay-nya.

5. Dapat mengeksekusi perintah tertentu ketika terjadi masalah atau terjadi kegagalan sistem.

6. Dapat mengeksekusi perintah tertentu jika pemakaian sumber daya melebihi ambang batas yang ditentukan.

Kebutuhan non-fungsional:

1. Status terkini hasil pemantauan dapat dilihat oleh petugas melalui antarmuka web.

2. Status layanan dan nilai persentase pemakaian suber daya diperoleh dengan mengeksekusi perintah melalui SSH tanpa password (passwordless SSH).

3. Memiliki file konfigurasi yang berisi:

- pengaturan database

- rincian target server yang akan dipantau

- perintah untuk mendapatkan nilai persentase pemakaian sumber daya

- perintah untuk mendapatkan status sebuah layanan

- nilai ambang batas pemakaian sumber daya dan perintah yang akan dieksekusi ketika pemakaian sumber daya melebihi ambang batas

- $\quad$ perintah yang akan dieksekusi ketika terjadi masalah pada sebuah layanan

4. Bahasa pemrograman menggunakan bahasa Python dan PHP.

5. Database untuk penyimpanan mengunakan MySQL.

\section{PERANCANGAN}

Perancangan sistem untuk pembuatan program ini dilakukan untuk memberikan gambaran tentang sistem yang dibuat.

\section{A. Diagram Alir}

Perancangan diagram alir untuk sistem ini adalah sebagai berikut: 


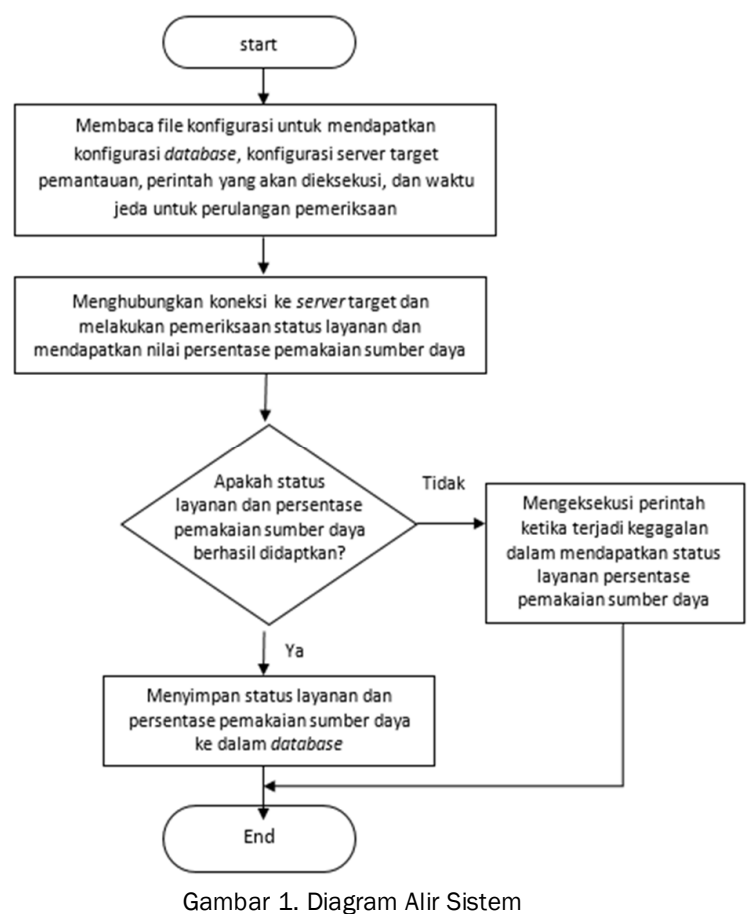

Diagram alir sistem pada gambar 1 di atas menggambarkan alur program yang dibuat, yaitu pertama program akan membaca file konfigurasi yang berisi pengaturan database, rincian server target pemantauan, perintah-perintah yang akan dieksekusi untuk mendapatkan status layanan dan nilai persentase pemakaian sumber daya, serta perintah yang akan dieksekusi ketika terjadi kegagalan ketika mendapatkan status layanan dan pemakaian sumber daya. Kemudian program akan menghubungkan koneksi ke server target pemantauan dan mulai melakukan pemantauan. Jika status layanan dan persentase pemakaian sumber daya berhasil didapatkan maka program akan menyimpan data tersebut ke dalam database, dan jika tidak berhasil maka program akan mengeksekusi perintah yang sudah diatur di dalam file konfigurasi.

B. Diagram Konseptual

Diagram konseptual ini bertujuan untuk memberikan gambaran cara kerja program, yaitu sebagai berikut:

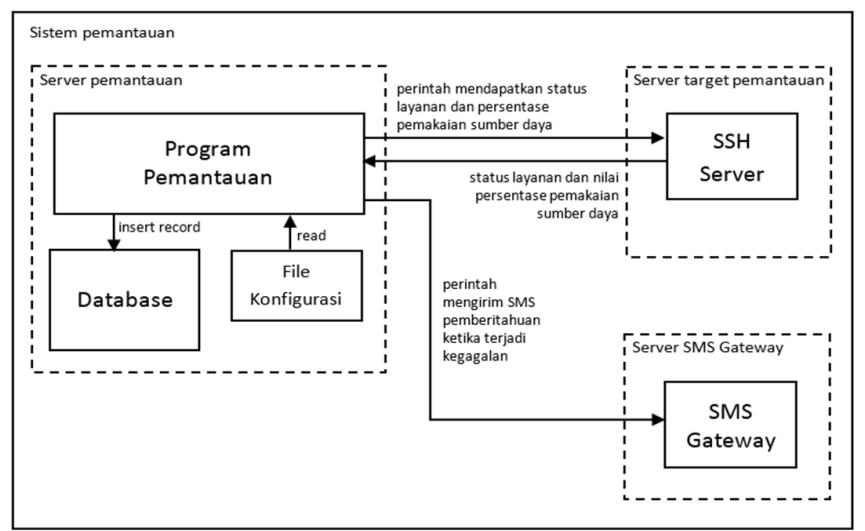

Gambar 2. Perancangan Konseptual

Gambar 2 menggambarkan perancangan konseptual dimana terdapat tiga buah bagian utama di dalam sistem yaitu server pemantauan, server target pemantauan, dan server SMS Gateway. Di dalam server pemantauan terdapat program utama untuk melakukan pemantauan, file konfigurasi, dan database. Sebelum melakukan pemantauan, program pemantauan membaca file konfigurasi terlebih dahulu kemudian mengeksekusi perintah untuk mendapatkan status layanan dan persentase pemakaian sumber daya pada server target pemantauan melalui protokol SSH. Sebelumnya, di 
dalam server target pemantauan harus sudah terpasang layanan SSH dan berjalan. Jika status layanan dan nilai persentase pemakaian sumber daya berhasil didapatkan, data tersebut kemudian disimpan di dalam database. Dan jika status layanan dan nilai persentase pemakaian sumber daya gagal didapatkan, maka program akan mengeksekusi perintah yang sudah diatur di dalam file konfigurasi. Pada pembuatan program ini perintah yang akan dieksekusi adalah perintah untuk melakukan pengiriman SMS pemberitahuan melalui server SMS gateway.

\section{HASIL DAN PEMBAHASAN}

Pembuatan perangkat lunak pemantauan menggunakan bahasa pemrograman Python. Library tambahan yang digunakan adalah os dan sys untuk mengeksekusi perintah sistem operasi, time dan datetime untuk fungsi waktu, pymysql untuk koneksi ke database MySQL, stomp untuk koneksi ke server messaging, random untuk membangkitkan angka acak, requests untuk mengirim permintaan ke server HTTP, ConfigParser untuk membaca file konfigurasi, dan multiprocessing untuk membuat banyak proses yang digunakan untuk memisahkan setiap eksekusi perintah pemeriksaan menjadi proses sendiri.

Untuk mendapatkan nilai persentase pemakaian sumber daya dilakukan dengan cara mengeksekusi perintah melalui SSH tanpa password (passwordless). Syarat untuk melakukan SSH tanpa password ini adalah harus memasang identitas pengguna dari server pemantau terlebih dahulu di dalam server yang akan dipantau. Dengan menggunakan SSH tanpa password ini pengguna dari server pemantau dapat mengeksekusi perintah di dalam server yang akan dipantau tanpa harus melakukan log- in terlebih dahulu.

Untuk melakukan perintah SSH digunakan pustaka untuk mengeksekusi perintah sistem operasi yang kemudian didapatkan pesan kembalian dari perintah tersebut untuk diolah oleh program. Perintah yang akan dieksekusi dapat diatur pada file konfigurasi, sehingga dapat disesuaikan dengan sistem operasi yang dipakai pada server target pemantauan.

Pada saat program dijalankan, dilakukan pemeriksaan file konfigurasi. Jika terdapat kesalahan pada file konfigurasi, program akan dihentikan dan menampilkan pesan kesalahan. Jika tidak terdapat kesalahan pada file konfigurasi, program akan berjalan dan membuat proses-proses baru sesuai dengan jumlah sumber daya dan layanan yang dipantau. Nilai persentase pemakaian sumber daya disimpan ke dalam database MySQL, data bertambah setiap interval tertentu sesuai dengan yang diatur di dalam file konfigurasi. Status layanan juga disimpan ke dalam database MySQL dan diperbaharui setiap interval tertentu sesuai dengan yang diatur di dalam file konfigurasi. Sama halnya juga dengan status layanan perpesanan dari server perpesanan yang dipantau.

\section{A. Antarmuka Web}

Untuk memudahkan petugas pemantauan maka dibuat antarmuka web untuk melihat status terkini dari layanan yang dipantau dan pemakaian sumber daya. Pembuatan antarmuka web menggunakan bahasa pemrograman PHP dengan framework Codelgniter. Terdapat dua controller utama yaitu controller Main yang digunakan untuk menampilkan halaman dashboard dan controller Get yang digunakan untuk mendapatkan data yang diperoleh dari database untuk ditampilkan di dashboard web. Di dalam controller Get terdapat tiga fungsi yaitu:

\section{- rmon(\$servername)}

Fungsi ini adalah untuk mendapatkan nilai persentase pemakaian sumber daya. Fungsi ini dapat diakses melalui URL http://<hostname> /dashboard/get/rmon/<nama_server> dengan data kembalian berupa JSON yang akan diolah oleh javascript di halaman dashboard dan kemudian ditampilkan nilai dan visualisasinya. Contoh data JSON yang diperoleh
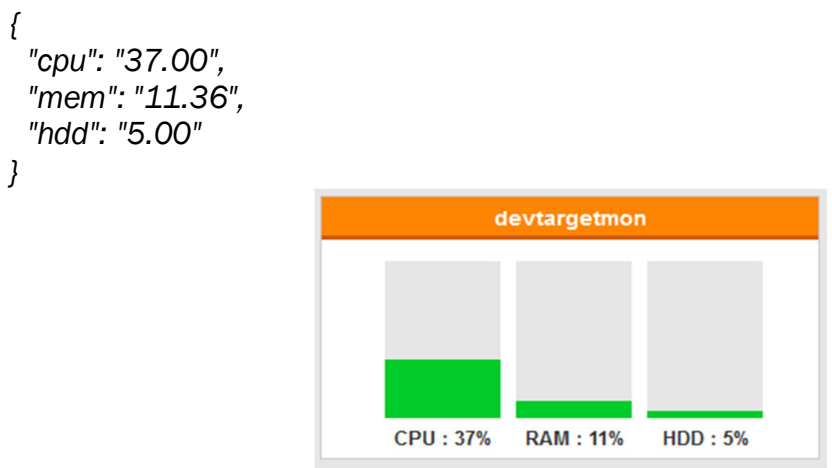

Gambar 3. Hasil visualisasi pemakaian sumber daya dari data JSON yang didapat 


\section{- svcstats()}

Fungsi ini adalah untuk mendapatkan semua status layanan yang dipantau. Fungsi ini dapat diakses melalui URL http://<hostname>/dashboard/get/svcstats dengan data kembalian berupa JSON yang akan diolah oleh javascript dan kemudian ditampilkan di halaman dashboard. Contoh data JSON yang diperoleh

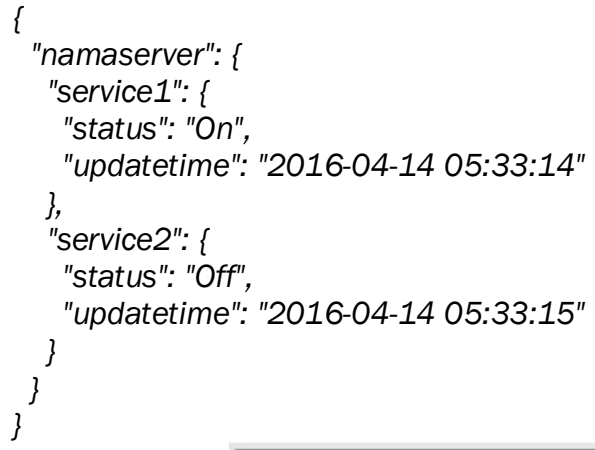

- messaging()

Fungsi ini adalah untuk mendapatkan status layanan perpesanan dan waktu delay-nya. Fungsi ini dapat diakses melalui URL $h t t p: / /<h o s t n a m e>/$ dashboard/get/svcstats dengan data kembalian berupa JSON yang akan diolah oleh javascript dan kemudian ditampilkan di halaman dashboard web.

Contoh data JSON yang diperoleh
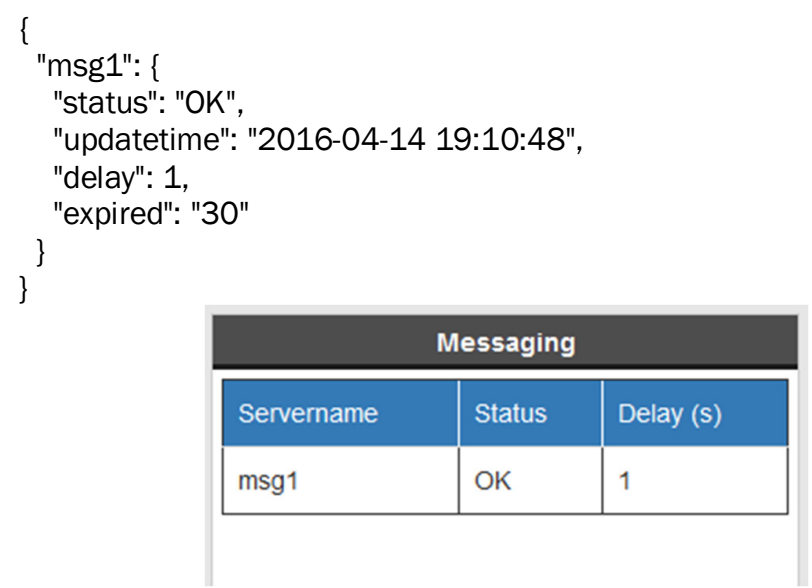

Gambar 5. Tampilan status layanan perpesanan

Untuk medapatkan statistik pengguna baru, digunakan API khusus di server eksternal yang diakses melalui protokol HTTP dengan parameter tambahan tanggal pertama dan tanggal ke dua sesuai dengan rentang yang dikehendaki dengan data kembalian berformat JSON. data JSON yang diperoleh

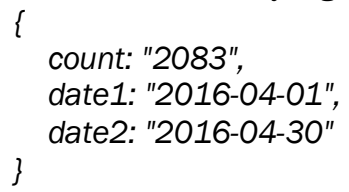




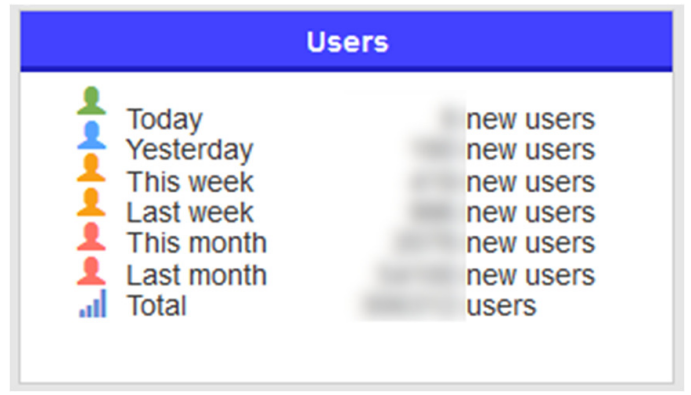

Gambar 6. Tampilan statistik pengguna baru

\section{B. Pengujian}

Pengujian perangkat lunak ini dilakukan di dalam sebuah server yang sudah disiapkan. Terdapat beberapa server target yang dipantau dengan beberapa service di dalamnya, dan terdapat sebuah server perpesanan. Rincian server yang akan dipantau dimasukkan ke dalam file konfigurasi dan selanjutya program dijalankan. Hasil dari pemantauan ditampilkan pada halaman web dashboard seperti pada gambar di bawah ini

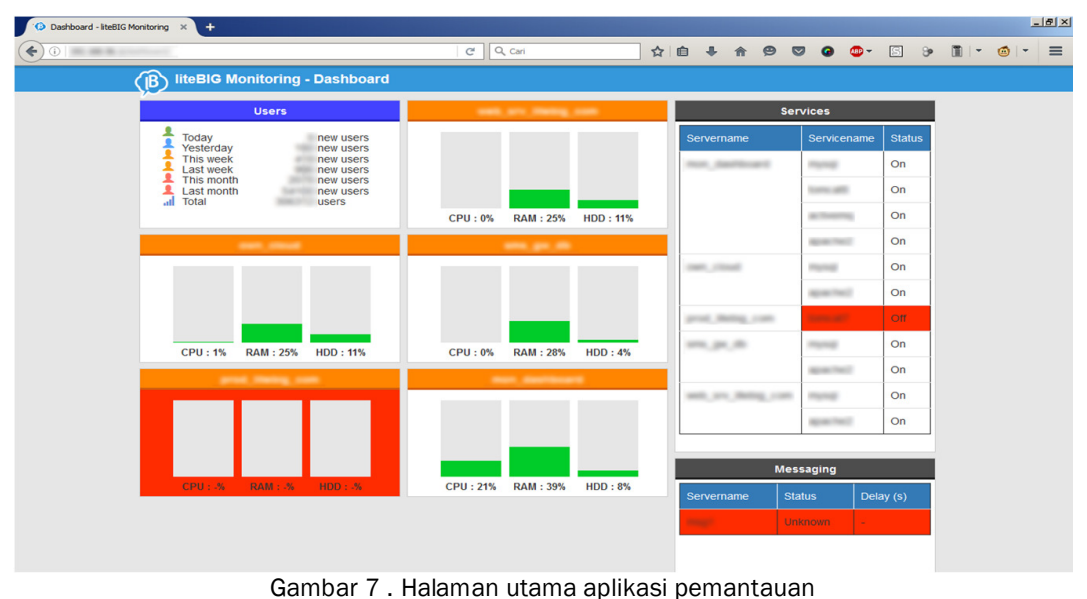

Gambar 7 merupakan salah satu tampilan pada saat pengujian. Dimana, terdapat 5 buah server yang sedang dipantau. Pada server nomor 1 pemakaian CPU sebesar 0\%, RAM sebesar 23\%, dan HDD sebesar 11\%. Pada server nomor 2 pemakaian CPU sebesar 1\%, RAM sebesar 25\%, dan HDD sebesar 11\%. Pada server nomor 3 pemakaian CPU sebesar 0\%, RAM sebesar 28\%, dan HDD sebesar 4\%. Pada server nomor 4 nilai persentase pemakaian sumber daya tidak diketahui, hal ini dikarenakan perangkat lunak pemantauan gagal terhubung ke server nomor 4 sehingga tidak dapat mengetahui persentase pemakaian sumber daya saat itu juga. Pada server nomor 5 pemakaian CPU sebesar $21 \%$, RAM sebesar 39\%, dan HDD sebesar 8\%.

Terlihat pada gambar di atas, server keempat pada bagian pemantauan sumber daya memiliki latar belakang berwarna merah yang berarti server tersebut tidak dapat diakses. Pada bagian pemantauan service di server ketiga terdapat service yang berstatus Off. Dan pada bagian pemantauan layanan perpesanan terdapat juga masalah pada server yang sedang dipanatau. Ketika terjadi masalah seperti ini, petugas pemantau akan melakukan pemeriksaan lebih lanjut terhadap server yang bermasalah tersebut dan melakukan tindakan yang diperlukan sehingga layanan dapat berjalan kembali.

Pengujian alert dilakukan dengan berbagai perlakuan. Pada pengujian status service, dilakukan dengan menonaktifkan salah satu service. Pada pengujian alert mendapatkan nilai persentase pemakaian sumber daya, dilakukan dengan mengubah nilai ambang batas. Perintah yang dieksekusi ketika terjadi masalah adalah perintah untuk mengakses URL untuk mengirim SMS melalui SMS Gateway dengan parameter tambahan berupa username, key, nomor ponsel tujuan, dan isi pesan. Contoh SMS pemberitahuan ketika terjadi masalah adalah seperti gambar di bawah ini 


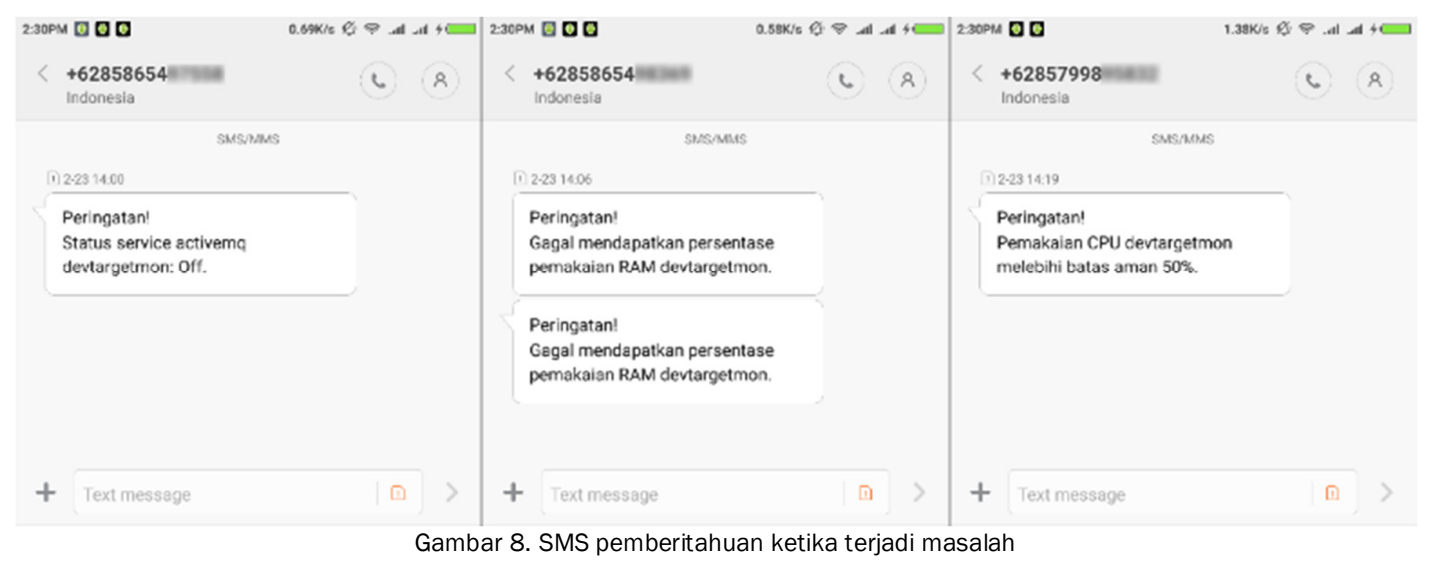

Gambar 8 di atas adalah hasil dari pengujian alert melalui SMS. Gambar nomor 1 adalah SMS pemberitahuan ketika salah satu service berstatus Off. SMS ini dikirimkan setelah dilakukan penonaktifan salah satu service yang sedang dipantau secara sengaja. Pada gambar nomor 2 adalah SMS pemberitahuan ketika perangkat lunak pemantau gagal terhubung ke server target pemantauan untuk mendapatkan nilai persentase pemakaian sumber daya RAM. SMS ini dikirimkan setelah koneksi ke server yang dipantau diputus secara sengaja. Dan pada gambar 3 adalah SMS peringatan ketika pemakaian salah satu sumber daya yaitu CPU melebihi threshold yang ditentukan pada file konfigurasi. Pada pengujian ini nilai threshold adalah 50, sehingga ketika pemakaian CPU melabihi 50\% maka SMS peringatan akan segera dikirimkan. Waktu rata-rata pengiriman SMS pemberitahuan untuk sampai ke petugas adalah kurang dari 30 detik.

\section{KESIMPULAN}

Kesimpulan yang diperoleh dari implementasi aplikasi pemantauan ini adalah sebagai berikut:

1. Dengan adanya perangkat lunak pemantauan layanan, petugas dapat mengetahui status terkini layanan yang sedang dipantau, pemakaian sumber daya (CPU, memory, dan harddisk), dan statistik pengguna baru liteBIG messenger melalui antarmuka web.

2. Petugas pemantauan menerima SMS pemberitahuan ketika terjadi kegagalan dalam waktu kurang dari 30 detik.

3. Pemberitahuan oleh perangkat lunak pemantauan dapat memberikan informasi lebih dini kepada petugas ketika terjadi masalah pada layanan.

4. Proses pengembangan aplikasi pemantauan berjalan dengan lancar, karena proses iterasi gathering-information yang intensif antar peneliti dan pihak LiteBig messenger.

\section{REFERENSI}

[1] G. F. Nama, H. D. Septama, L. Hakim, M. Komarudin, "Rancang Bangun Sistem Monitoring Sambungan Internet Universitas Lampung Berbasis Mini Single Board Computer BCM2835”, Prosiding Seminar Nasional Sains \& Teknologi V Satek \& Indonesia Hijau, ISBN : 978-979-8510-71-7, Bandar Lampung, hal. 73-83, 2013.

[2] D. Despa, D, A. Kurniawan, M. Komarudin, Mardiana, G. F. Nama, "Smart monitoring of electrical quantities based on single board computer BCM2835", 2nd International Conference on Information Technology, Computer, and Electrical Engineering, pp 315-320, Indonesia, 2015.

[3] Microsoft Official Academic Course. 2010. Windows Server Administration Fundamentals. New York: John Wiley and Sons.

[4] http://appdevelopermagazine.com/2104/2014/11/19/Why-Mobile-App-Development-Requires-More-than-an-SOA), 2016

[5] Stiawan, Deris. 2005. Sistem Keamanan Komputer. Jakarta: PT. Elex Media Komputindo.

[6] Utami, E., Raharjo, S. 2004. Logika Algoritma dan Implementasinya dalam Bahasa Python di GNU/Linux. Yogyakarta: Andi.

[7] Mount, S., Shuttleworth, J., Winder, R. 2008. Python for Rookies: A First Course in Programming. London: Thomson Learning (EMEA) Ltd.

[8] Sulaiman, H.A., Othman, M.A., Othman, M.F.I, Rahim, Y.A., Pee, N.M. 2014. Advanced Computer and Communication Engineering Technology. Malaysia: Springer.

[9] Riyanto, R. O. Wiyagi, Sistem Monitoring Suhu Ruang Server Berbasis Web. Junal IImiah Elite Elektro, 2(1), pp. 50 - 54, 2011.

[10] G. F. Nama, M. Ulvan, A. Ulvan, A. M. Hanafi, "Design and Implementation of Web-Based Geographic Information System for Public Services in Bandar Lampung City - Indonesia". International Conference on Science in Information Technology (ICSITech), pp 270-275, Yogyakarta, Indonesia, 2015.

[11] G. F. Nama, M. Komarudin, H. D. Septama, "Performance Analysis of ArubaTM Wireless Local Area Network Lampung University". International Conference on Science in Information Technology (ICSITech), pp 41-46, Yogyakarta, Indonesia, 2015.

G. F. Nama, M. Komarudin, H. Priambodo, Mardiana, H. D. Septama, “Electricity, Temperature, and Network Utilization Monitoring at Lampung University Data Centre Using Low Cost Low Power Single Board Mini Computer". Regional Conference on Computer Information Engineering, Indonesia, pp. 184-189, 2014. 